\begin{tabular}{cc|c}
\hline Tar. Bil. Der. & Tarım Bilimleri Dergisi & Journal of Agricultural Sciences \\
& $\begin{array}{c}\text { Dergi web sayfası: } \\
\text { www.agri.ankara.edu.tr/dergi }\end{array}$ & Journal homepage: \\
& www.agri.ankara.edu.tr/journal
\end{tabular}

\title{
Phosphorus Fractions and Cycling in the Sediment of a Shallow Eutrophic Pond
}

\author{
Akasya TOPÇU ${ }^{a}$, Serap PULATSÜ ${ }^{a}$ \\ ankara University, Faculty of Agriculture, Department of Fisheries and Aquaculture Engineering, Diskapi, 06110, Ankara, TURKEY
}

\section{ARTICLE INFO}

Research Article-Animal Production DOI: 10.1501/Tarimbil 0000001266

Corresponding Author: Akasya TOPÇU, E-mail: atopcu@ankara.edu.tr, Tel:+90 (312) 5961648

Received: 12 July 2013, Received in Revised Form: 22 December 2013, Accepted: 03 January 2014

\begin{abstract}
The aim of this study was to quantitatively determine the phosphorus fractional composition of the eutrophicated West Pond sediment using vertical and seasonal changes (positive-upwards and/or negative-downwards) in the phosphorus cycling across the sediment-water, and to examine the most effective potential fraction or fractions on phosphorus release and the pond's eutrophication process. In this study, mean release values of phosphorus in depths and months representing the seasons (April, July, October, January) varied between 9.19 (January, 0-5 cm) and $119.08 \mu \mathrm{g} \mathrm{m}^{-2} \mathrm{~d}^{-1}$ (October, 0-5 cm) in West Pond sediment which supplies water to the Sakaryabaş1 Fish Culture and Research Station. The mean negative phosphorus release dependent on months and depths were estimated as $1.25 \mu \mathrm{g} \mathrm{m}^{-2} \mathrm{~d}^{-1}$ (July, 5-10 $\mathrm{cm}$ ) and $46.45 \mu \mathrm{g} \mathrm{m}^{-2} \mathrm{~d}^{-1}$ (October, 10-15 cm). The distribution of phosphorus fractions in the pond sediment: total organically bound phosphorus fraction $(\mathrm{Org} \approx \mathrm{P})>$ calcium bound phosphorus fraction $(\mathrm{Ca} \approx \mathrm{P})>$ carbonate bound phosphorus fraction $\left(\mathrm{CO}_{3} \approx \mathrm{P}\right)>$ iron + aluminum bound phosphorus fraction $(\mathrm{Fe}+\mathrm{Al} \approx \mathrm{P})$. In line with research findings the negative phosphorus release dependent on months and depths have revealed quantitatively that West Pond sediment is a sink not a source in terms of phosphorus. In the light of this, conservation of the aquatic macrophytes, role in preventing/suppressing the dissolved inorganic phosphorus release from sediment to overlying water, suggested as the best management technique of West Pond.
\end{abstract}

Keywords: Sediment; Phosphorus release; Sediment porewater; West pond

\section{Sı̆̆ Ötrofik Gölet Sedimentinde Fosfor Fraksiyonları ve Döngüsü}

\section{ESER BILGİí}

Araştırma Makalesi-Hayvansal Üretim

Sorumlu Yazar: Akasya TOPÇU, E-posta: atopcu@ankara.edu.tr. Tel:+90 (312) 5961648

Geliş Tarihi:12 Temmuz 2013, Düzeltmelerin Gelişi: 22 Aralık 2013, Kabul: 03 Ocak 2014

\section{ÖZET}

Bu araştırmanın amacı, ötrofik Batı Göleti sedimentinde fosfor fraksiyon kompozisyonunun, sediment-su ara yüzeyindeki fosforun vertikal (pozitif-yukarı yönde ve/veya negatif- aşağı yönde) ve mevsimsel değişiminin kantitatif olarak 
belirlenmesi ile fosfor salınımında potansiyel etkili fraksiyon veya fraksiyonların ortaya konmasıdır. Bu araştırmada, Sakaryabaşı Balık Üretim ve Araştırma İstasyonu'nun su kaynağı Batı Göleti'nde sedimentten olan fosfor salınım ortalamalarının derinlik ve mevsimleri temsil eden aylara (Nisan, Temmuz, Ekim, Ocak) bağlı değişimi $9.19 \mu \mathrm{g} \mathrm{m} \mathrm{m}^{-2} \mathrm{gün}^{-1}$ (Ocak, 0-5 cm) ve $119.08 \mu \mathrm{g} \mathrm{m}^{-2} \mathrm{gün}^{-1}$ (Ekim, 0-5 cm) olarak tespit edilmiştir. Aylara ve derinliklere bağlı ortalama negatif fosfor salınımı $1.25 \mu \mathrm{g} \mathrm{m}^{-2}$ gün $^{-1}$ (Temmuz, 5-10 cm) ve $46.45 \mu \mathrm{g} \mathrm{m}^{-2}$ gün $^{-1}$ (Ekim, 10-15 cm) olarak hesaplanmıştır. Gölet sedimentinde fosfor fraksiyonlarının dağılımı; toplam organik bağlı fosfor fraksiyonu (Org $\approx$ P) $>$ kalsiyuma bağlı fosfor fraksiyonu $(\mathrm{Ca} \approx \mathrm{P})>$ karbonata bağlı fosfor fraksiyonu $\left(\mathrm{CO}_{3} \approx \mathrm{P}\right)>$ demir + alüminyuma bağlı fosfor fraksiyonu $(\mathrm{Fe}+\mathrm{Al} \approx \mathrm{P})$ olarak saptanmıştır. $\mathrm{Bu}$ araştırmada elde edilen aylara ve derinliklere bağlı negatif fosfor salınım verileri doğrultusunda; Batı Göleti sedimentinin fosfor kaynağı değil fosfor tuzağı olduğu kantitatif olarak ortaya konmuştur. Bu bağlamda, Batı Göleti'nde sedimentten suya fosfor geçişinin engellenmesine veya baskılanmasına ilişkin en iyi yönetim uygulaması sucul makrofitlerin korunması olarak gözükmektedir.

Anahtar Kelimeler: Sediment; Fosfor salınımı; Sediment gözenek suyu; Batı göleti

(C) Ankara Üniversitesi Ziraat Fakültesi

\section{Introduction}

Phosphorus is a key element in determining trophic state of aquatic systems. Sediments in aquatic systems are the main components of limnological studies and play a critical role in the phosphorus cycle as a source or a sink for phosphorus. In aquatic systems, phosphorus mobility in the sediment-water interface, depending on some physical and chemical environmental conditions, are defined to form phosphorus compounds (Gerhardt \& Schink 2005). The chemical phosphorus fractination of sediment has a vital importance in the determination of the most effective phosphorus fraction in the release of phosphorus from the sediment to the water (Kisand 2005).

Macrophytes present especially in shallow lakes show a positive or negative effect on triggering or blocking the release of phosphorus from sediment (Qu et al 2003; Schneider \& Melzer 2004). West Pond, converted to a pond, is one of five karst springs located in Central Anatolia. Some researches were conducted taking into account the pond's sediment and water characteristics (Akcora Topçu 2001; Akcora Topçu 2002; Pulatsü et al 2003; Pulatsü \& Topçu 2006; Topçu \& Pulatsü 2011).

The aim of this study was to quantitatively determine the phosphorus fractional composition of the eutrophic West Pond sediment using vertical $(5.0 \mathrm{~cm}$ sampling intervals across $20 \mathrm{~cm}$ sediment depth) and seasonal changes (positive and/or negative) in the phosphorus release, and to examine the most effective potential fraction or fractions on phosphorus cycling across the sediment-water and the pond's eutrophication process. Moreover to decide the proper management technique will be another target of this research.

\section{Material and Methods}

\subsection{Study site}

The Sakaryabaşı Karst Springs located in Central Anatolia (Latitude $39.21 \mathrm{~N}$, Longitude $31.02 \mathrm{E}$ ) belong to a confined-semi confined karst aquifer, has a thermal component (Günay et al 2001). West Pond is one of the five Sakaryabaşı Karst Springs which was converted to a pond. The pond supplies water to the Rainbow Trout Culture and Research station, with a capacity of $40 \mathrm{t} \mathrm{y}^{-1}$. The temperature of the pond's water has a limited range $\left(16-22^{\circ} \mathrm{C}\right)$ throughout the year. West Pond has a 0.92 ha surface area and the mean depth during the sampling period was $2.8 \mathrm{~m}$.

\subsection{Field work}

The sampling station was macrophyte dominated, sampling was carried out in April-2009, July-2009, October-2009 and January-2010 in a station near the inlet of the trout farm (Figure 1). Sediment samples were collected from the pond by using plexi-glasse tubes $(5.0 \mathrm{~cm}$ inner diameter; $20 \mathrm{~cm}$ length). Sediment samples were transported to the 
laboratory by preserving in a liquid nitrogen tank in order to avoid disturbance. Sediment samples were sliced after sampling; with the sampling intervals being $0-5 \mathrm{~cm}, 5-10 \mathrm{~cm}, 10-15 \mathrm{~cm}$ and $15-20 \mathrm{~cm}$, respectively.

Lake water samples were collected by siphoning from $10 \mathrm{~cm}$ above the sediment-water interface. The temperature, dissolved oxygen concentration (YSI Pro 20 ; measures temperature $5{ }^{\circ} \mathrm{C}-45{ }^{\circ} \mathrm{C}$ with $\pm 1{ }^{\circ} \mathrm{C}$ sensitivity, dissolved oxygen 0 ppm- $15 \mathrm{ppm}$ with $\pm 0.2 \mathrm{ppm}$ sensitivity) and $\mathrm{pH}$ of the overlying water were measured in situ with YSI-pH $100( \pm 1$ ${ }^{\circ} \mathrm{C}$ sensitivity) portable instruments.

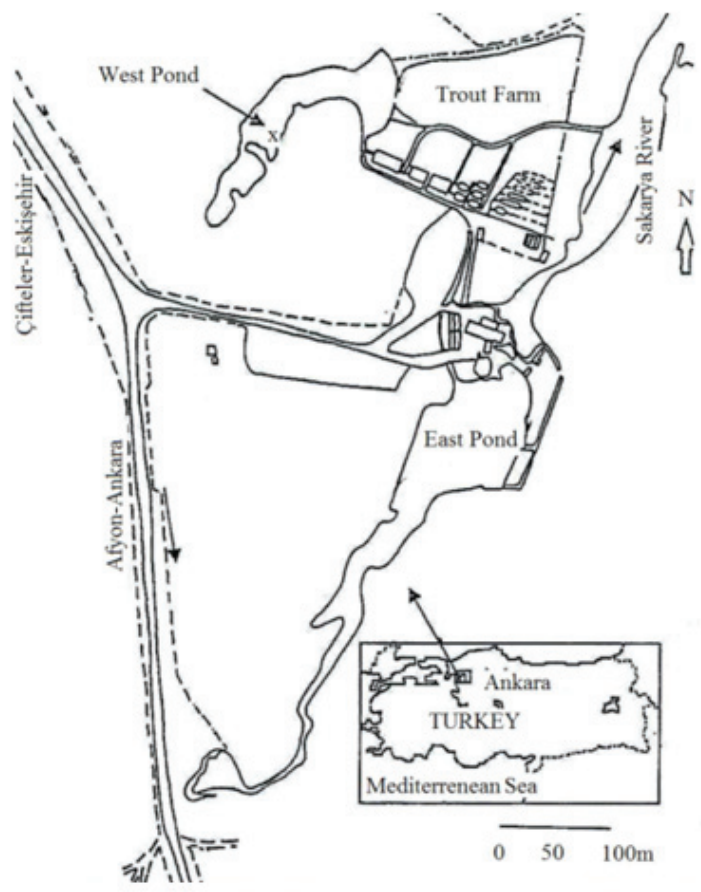

Figure 1- Location of the study area in West Pond (X, sampling point)

Şekil 1- Batı Göleti'nde araştırma alanı (X, araştırma istasyonu)

\subsection{Laboratory analyses}

Potential phosphorus release from the sediments into the lake water by molecular diffusion was calculated by Berner (1980) (Shaw and Prepas 1990). Concentration profiles were used to calculate the diffusive flux of soluble reactive phosphorus (SRP) across the sediment-water interface, based on Fick's First Law of Diffusion (Shaw and Prepas 1990), according to the Equation 1:

FLUX $=\varphi \cdot D \cdot Q^{-2} \cdot d c / d c \cdot 86400$

Where; FLUX, SRP flux across the sediment-water interface (in $\mathrm{mg} \cdot \mathrm{m}^{-2} \mathrm{~d}^{-1}$ ); $\varphi$, the water content by volume (dimensionless); $\mathrm{D}$, molecular diffusion coefficient (varies according to temperature); $\mathrm{Q}^{-2}$, tortuosity term $(\varphi-0.8$; [Shaw and Prepas $1990]) ; \mathrm{dc} / \mathrm{dc}$, the SRP gradients across the sediment-water interface $\left(\mathrm{mg} \mathrm{m}^{-4}\right) ; 86400$, the factor to convert $\mathrm{s}$ to $\mathrm{d}$.

The dried sediments $\left(105^{\circ} \mathrm{C}, 24 \mathrm{~h}\right)$ was analysed for total phosphorus spectrophotometrically after digestion in a mixture of oxidizing acids. Sediment phosphorus fractionations were determined with the method of Hieltjes and Lijklema (1980) including (i) loosely-sorbed phosphorus $\left(\mathrm{CO}_{3} \approx \mathrm{P}\right.$, extracted for $2 \mathrm{~h}$ with $1 \mathrm{M} \mathrm{NH}_{4} \mathrm{Cl}$ ); (ii) iron-plus-aluminumbound phosphorus $(\mathrm{Fe}+\mathrm{Al} \approx \mathrm{P}$, extracted for $17 \mathrm{~h}$ with $0.1 \mathrm{~N} \mathrm{NaOH}$ ); and (iii) calcium-bound phosphorus $(\mathrm{Ca} \approx \mathrm{P}$, extracted for $24 \mathrm{~h}$ with $0.5 \mathrm{~N} \mathrm{HCl})$. Organicbound phosphorus (org $\approx \mathrm{P}$ ) was calculated from the difference between total phosphorus and the sum of the inorganic fractions.

The sediment water content was determined by drying at $110^{\circ} \mathrm{C}$ for $16 \mathrm{~h}$, and loss on ignition (LOI) was determined by the loss of weight during ignition at $550{ }^{\circ} \mathrm{C}$ for $2 \mathrm{~h}$. The total iron concentrations were measured with Atomic Adsorption/Flame Emission Spectroscopy (Varian Spectro AAS standard range 0-5 with $248.3 \mathrm{~nm}$ wave length) (APHA 1995). All the parameters were measured on all sections of the sediment and reported on a dry-weight basis.

Sediment pore water was obtained by centrifuging sediment samples at a rate of $3000 \mathrm{rpm}$ for 20 seconds, and sediment overlying water was gained by siphoning from the water, $10 \mathrm{~cm}$ above the sediment. Water from these samples was analyzed after filtering from a $0.45 \mu \mathrm{m}$ membrane filtrate in duplicate for soluble reactive P (SRP) according to APHA (1995). Moreover iron concentrations in these samples were determined by using Phenantroline Method according to APHA (1995). 


\subsection{Statistical analyses}

ANOVA, and Duncan's multiple-range test were used to evaluate differences in sediment and water between months and depths using the Minitab and MStat programs for Windows.

\section{Results and Discussion}

In this study, potential release of phosphorus from the sediment to the lake water by molecular diffusion (flux) ranged from $9.19 \mu \mathrm{g} . \mathrm{m}^{-2} \mathrm{~d}^{-1}$ in July 2009 (0-5 $\mathrm{cm})$ to $119.08 \mu \mathrm{g} \cdot \mathrm{m}^{-2} \mathrm{~d}^{-1}$ in October $2009(0-5 \mathrm{~cm})$. The mean negative phosphorus release (retention) according to months and sections was between 1.25 $\mu \mathrm{g} \cdot \mathrm{m}^{-2} \mathrm{~d}^{-1}$ (January 2010; 5-10 cm section) and 46.45 $\mu \mathrm{g} . \mathrm{m}^{-2} \mathrm{~d}^{-1}$ (October 2009; 10-15 cm) (Figure 2).

In West Pond, the differences of the sediment's mean phosphorus fractions, total iron, total organic carbon, water content and LOI values in April-2009, July2009, October-2009 and January-2010 were found to be statistically significant $(P<0.05$, Figure 3$)$. In this study, porewater SRP concentrations generally showed clear differences with relation to depth. According to the variance analysis, there was an interaction between months and sediment sections regarding SRP, TFe concentrations $(P<0.05$, Table 1$)$.

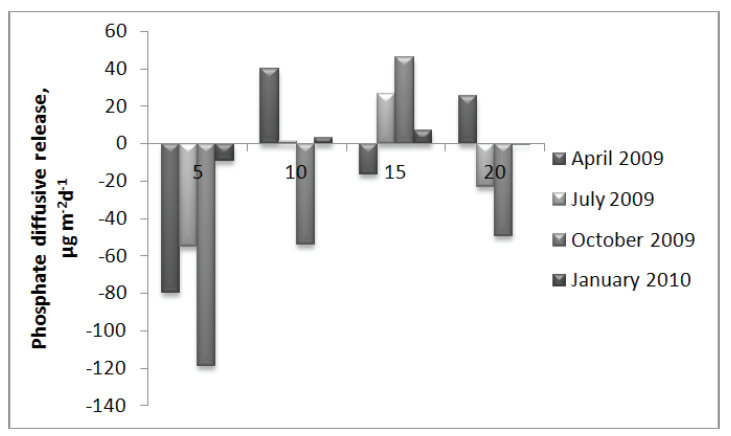

Figure 2- Phosphate diffusive release in the sediment sections $(0-5 \mathrm{~cm}, 5-10 \mathrm{~cm}, 10-15 \mathrm{~cm}$ and $15-20 \mathrm{~cm})$ of the West Pond according to months

Şekil 2- Batı Göleti sediment katmanlarında aylara bağlı difüzyonel fosfor salınımı

Table 1- Porewater SRP, TFe and $\mathrm{pH}$ values according to sediment sections and months in West Pond Çizelge 1- Batı Göleti'nde sediment gözenek suyu SRP, TFe ve $p H$ değerlerinin sediment katmanları ve aylara bağlı değişimi

\begin{tabular}{clccc}
\hline Months Sections (cm) & \multicolumn{1}{c}{$\begin{array}{c}\text { SRP } \\
\left(\mathrm{mg} \mathrm{m} \mathrm{m}^{-3}\right)\end{array}$} & $\begin{array}{c}\text { TFe } \\
\left(\mathrm{mg} \mathrm{m} \mathrm{m}^{-3}\right)\end{array}$ & $p H$ \\
\hline \multirow{3}{*}{ April } & $0-5$ & $194.84 \pm 0.79^{\mathrm{d}^{\mathrm{a}}}$ & $213.46 \pm 6.66^{\mathrm{c}}$ & $7.58 \pm 0.03^{\mathrm{b}}$ \\
2009 & $5-10$ & $271.83 \pm 2.38^{\mathrm{b}}$ & $236.54 \pm 13.03^{\mathrm{b}}$ & $7.61 \pm 0.01^{\mathrm{a}}$ \\
& $10-15$ & $198.84 \pm 0.82^{\mathrm{c}}$ & $317.31 \pm 11.54^{\mathrm{a}}$ & $7.62 \pm 0.02^{\mathrm{a}}$ \\
& $15-20$ & $286.51 \pm 1.59^{\mathrm{a}}$ & $187.50 \pm 5.77^{\mathrm{d}}$ & $7.59 \pm 0.01^{\mathrm{b}}$ \\
\hline \multirow{3}{*}{ July } & $0-5$ & $128.17 \pm 1.52^{\mathrm{a}}$ & $135.58 \pm 5.77^{\mathrm{d}}$ & $7.09 \pm 0.01^{\mathrm{b}}$ \\
2009 & $5-10$ & $129.13 \pm 1.48^{\mathrm{a}}$ & $227.88 \pm 5.71^{\mathrm{c}}$ & $7.11 \pm 0.01^{\mathrm{a}}$ \\
& $10-15$ & $82.14 \pm 0.79^{\mathrm{c}}$ & $271.15 \pm 24.47^{\mathrm{a}}$ & $7.11 \pm 0.01^{\mathrm{a}}$ \\
& $15-20$ & $119.44 \pm 0.80^{\mathrm{b}}$ & $253.85 \pm 23.02^{\mathrm{b}}$ & $7.06 \pm 0.01^{\mathrm{c}}$ \\
\hline \multirow{3}{*}{ October } & $0-5$ & $146.03 \pm 1.30^{\mathrm{a}}$ & $178.85 \pm 19.99^{\mathrm{c}}$ & $7.07 \pm 0.02^{\mathrm{a}}$ \\
2009 & $5-10$ & $79.37 \pm 1.28^{\mathrm{c}}$ & $204.81 \pm 5.77^{\mathrm{b}}$ & $7.05 \pm 0.01^{\mathrm{b}}$ \\
& $10-15$ & $107.54 \pm 0.75^{\mathrm{b}}$ & $213.46 \pm 6.66^{\mathrm{a}}$ & $7.02 \pm 0.01^{\mathrm{c}}$ \\
& $15-20$ & $62.30 \pm 0.78^{\mathrm{d}}$ & $204.81 \pm 5.71^{\mathrm{b}}$ & $7.07 \pm 0.02^{\mathrm{a}}$ \\
\hline \multirow{3}{*}{ January } & $0-5$ & $46.03 \pm 1.30^{\mathrm{a}}$ & $196.15 \pm 9.42^{\mathrm{a}}$ & $7.20 \pm 0.03^{\mathrm{a}}$ \\
2010 & $5-10$ & $40.87 \pm 0.75^{\mathrm{b}}$ & $118.27 \pm 14.52^{\mathrm{d}}$ & $7.16 \pm 0.02^{\mathrm{b}}$ \\
& $10-15$ & $28.97 \pm 0.78^{\mathrm{d}}$ & $144.23 \pm 11.54^{\mathrm{c}}$ & $7.19 \pm 0.01^{\mathrm{a}}$ \\
& $15-20$ & $30.16 \pm 0.30^{\mathrm{c}}$ & $193.27 \pm 5.71^{\mathrm{b}}$ & $7.11 \pm 0.01^{\mathrm{c}}$ \\
\hline
\end{tabular}

*, In the same column, the difference between means have different small letters are statistically significant $(P<0.05)$ 


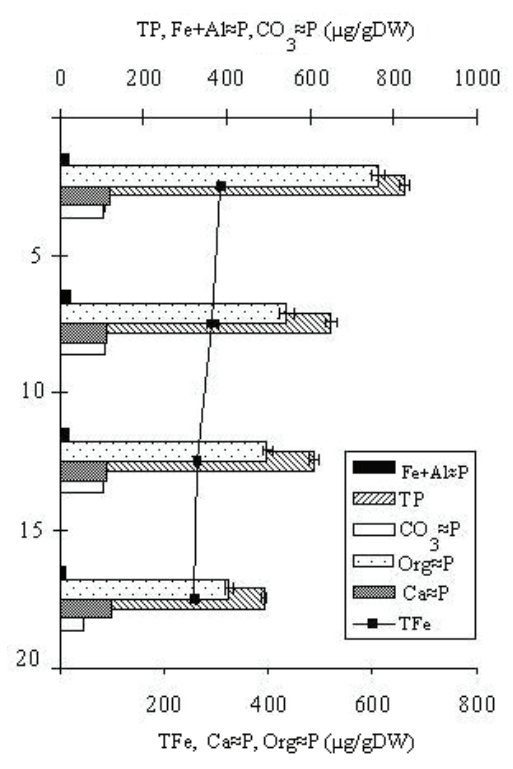

April-2009

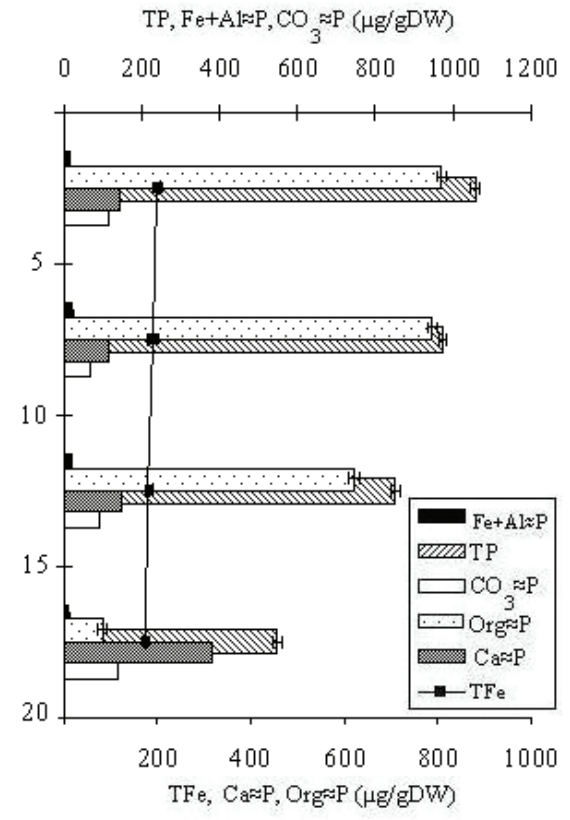

October-2009

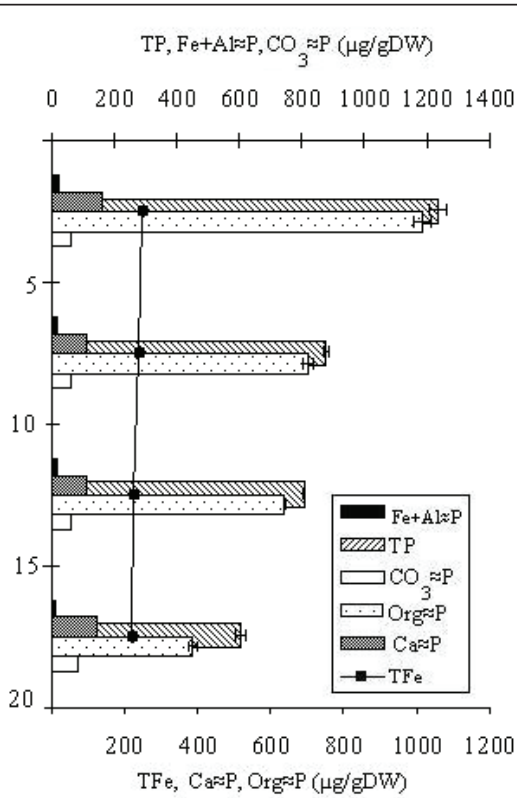

July-2009

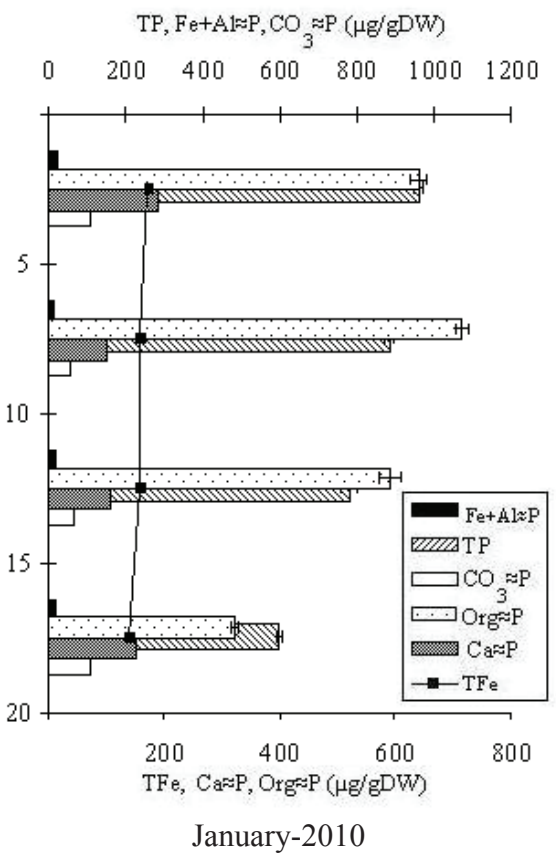

Figure 3- Phosphorus fractions and total iron concentrations according to months in the sediment sections of West Pond

Şekil 3- Batı Göleti sediment katmanlarında aylara bă̆lı fosfor fraksiyonları ve demir konsantrasyonları 
The mean values of water temperature, dissolved oxygen and $\mathrm{pH}$ variations according to months were found to be statistically significant $(P<0.05)$. The dissolved oxygen $\left(\mathrm{DO}_{2}\right)$ concentration of the overlying water never showed an anaerobic condition with a range of 5.85-7.28 $\mathrm{mg} \mathrm{L}^{-1}$ during the study period. Overlying water temperature ranged between $19.23 \pm 0.05{ }^{\circ} \mathrm{C}$ and $21.28 \pm 0.06{ }^{\circ} \mathrm{C}$ and $\mathrm{pH}$ varied from $7.09 \pm 0.0$ to $7.62 \pm 0.01$. In this research porewater and overlying water's $\mathrm{pH}$ values were found to be quantitatively similar.

The variations of the mean SRP and TFe concentrations of overlying water according to months were found to be statistically significant $(P<0.05)$. SRP values reached a maximum of $51.59 \pm 1.90 \mu \mathrm{g} \mathrm{L}^{-1}$ in July in parallel with the increase in water temperature, falling to a minimum of $33.33 \pm 0.83 \mu \mathrm{g} \mathrm{L}^{-1}$ in January. The range of TFe concentration of overlying water showed a similar trend regarding months, the minimum and the maximum values were as $80.75 \pm 5.69 \mu \mathrm{g} \mathrm{L}^{-1}$ and $126.92 \pm 7.62 \mu \mathrm{g} \mathrm{L}^{-1}$, respectively.

In this study sediment phosphorus release (negative and/or positive) between the sections did not show a regular change. In light of our data concerning the estimated low level of phosphorus release, West Pond's sediment does not quantitatively affect its trophic level. The highest value of the sediment phosphorus release in West Pond was estimated as $119.08 \mu \mathrm{g} \mathrm{m}^{-2} \mathrm{~d}^{-1}$ in October, $(0-5 \mathrm{~cm}$ sediment section) (Figure 2.), our findings are in keeping with the findings of Pulatsü \&Topçu (2006). In this study the estimated low-level phosphorus release values considering $5 \mathrm{~cm}$ intervals in $20 \mathrm{~cm}$ sediment depth were found to be quantitatively lower than the above researchers' values.

Rooted aquatic macrophytes are the main source of nitrogen and phosphorus in aquatic systems. Upon their death they release these nutrients into the sediment, thus increasing the storage of phosphorus in the sediment. Aquatic plant biomass in the same station in West Pond ranged from 41.0 to $103 \mathrm{~g} \mathrm{DW}$ $\mathrm{m}^{-2}$; the lowest value was found in October, while the highest value was in the period of March-April (Kırkağaç \& Demir 2006). Taking into account James et al (2004), because of the dense macrophyte presence at the research station in West Pond, phosphorus release from the sediment was very low, or in other words, prevented. Moreover, the presence of macrophytes in aquatic systems creates oxygen in the sediment, causing phosphorus release from the sediment into the lake water to remain at low levels (Qu et al 2003, Schneider \& Melzer 2004). Our findings concerning the low level of phosphorus release is in agreement with the above findings.

In the present study, the concentration of iron in the overlying water $\left(80.77-126.92 \mu \mathrm{g} \mathrm{L}^{-1}\right)$ was found to be lower than that of the sediment pore water (118.27-317.31 $\mathrm{g} \mathrm{L} \mathrm{L}^{-1}$ ) (Table 1.). This is another factor supporting the perpetuation of low phosphorus release from the sediment (Bostan et al 2000; Krogerus \& Ekholm 2003). Additionally, the high calcium content of the pond $(62.13 \pm 1.08 \mathrm{mg}$ $\mathrm{L}^{-1}-87.26 \pm 1.75 \mathrm{mg} \mathrm{L}^{-1}$ ) was shown to support the estimated low phosphorus release of the sediment.

In this study the fractional distribution of sediment phosphorus fractions was found to be: total organically bound phosphorus $(68.72 \%)>$ Calcium bound phosphorus (17.37\%) > Carbonate bound phosphorus $(11.72 \%)>$ Iron + Aluminium bound phosphorus (2.18\%) (Figure 3). The pond's sediment organically bound phosphorus fraction made up the highest component of phosphorus in all crosssections. In a study of the same pond conducted by Pulatsu et al (2003), organically bound phosphorus proved to be the dominant phosphorus composition of the sediment during the months of October, January and April. This finding points to the fact that sediment organically bound phosphorus fractions play an important role in preventing phosphorus release from the sediment, as explained by Marsden (1989).

In a study investigating the distribution characteristics of phosphorus and its species in sediments from Lake Hongfeng based on sequential extraction by Jiang et al (2011) the effectual inorganic phosphorus fractions component on preventing the sediment phosphorus release was mainly calcium bound phosphorus fraction due to the typical karstic limestone environment of the lake. Researchers concluded that $\mathrm{Ca} \approx \mathrm{P}$ fraction is a relatively stable, inert and non-bioavailable phosphorus fraction that may temporarily control the release of phosphorus from sediments. In West Pond the highest percentage of inorganically bound 
phosphorus fractions is the $\mathrm{Ca} \approx \mathrm{P}$ fraction $(17.37 \%)$. The calcareous rock makeup of the pond basin and the fact that the $\mathrm{Ca} \approx \mathrm{P}$ fraction in the pond sediment shows no regular variation have both negative and positive effects on phosphorus release. It is thought that the carbonate bound phosphorus which comes second to the calcium bound phosphorus within the inorganic phosphorus fractions of the pond sediment is also responsible for the observed variable phosphorus release. Our findings related with a low level of organic matter in the sediment support the line of reasoning reported by Boyd et al (1994) and Istvanovics (1994) regarding low levels of phosphorus release from the sediment and phosphorus retention in the sediment.

In our study, the SRP values of the sediment pore water varied between $28-286 \mu \mathrm{g} \mathrm{L}^{-1}$; in this context, taking into account the high concentration of macrophytes at the station, it is thought that the low level of phosphorus release and the retention of phosphorus are directly related with the presence of macrophytes.

An average TFe/SRP value of 2.5 was recorded for the sediment pore water of West Pond. This result supports the reports of Shaw \& Prepas (1990) regarding the relation between the iron-tophosphorus ratio in the sediment pore water and the low value or prevention of phosphorus release from the sediment. In our study in general, sediment pore water $\mathrm{pH}$ values varied between 7.02-7.62. The sediment pore water $\mathrm{pH}$ values during the research period did not reach the high $\mathrm{pH}$ values that Eckert et al (1997) described as possibly causing the release of phosphate from $\mathrm{Fe}(\mathrm{III})$ hydroxides.

The dissolved oxygen level of the overlying water did not affect the extremely low values of phosphorus release or retention estimated in West Pond. During the study period the difference in water temperature of West Pond $\left(18.53-21.28^{\circ} \mathrm{C}\right)$ was not recorded at a level that would have affected phosphorus release from the sediment to the water. The $\mathrm{pH}$ values found in our research (7.09-7.62) were not seen to be high enough to encourage phosphorus release from the sediment into the lake water. During the research period in West Pond the total filterable orthophosphate value of the overlying water changed between $33.33 \mu \mathrm{g} \mathrm{L}^{-1}$ and $51.59 \mu \mathrm{g} \mathrm{L}^{-1}$. Thus, when the results of Ramm \& Scheps (1997)'s findings regarding the effect of overlying water SRP values of more than $0.11 \mathrm{mg}$ $\mathrm{L}^{-1}$ on phosphorus release are taken into account, it is not possible to mention the release of phosphorus from the sediment in West Pond.

In conclusion, this study addresses the phosphorus fractions in the sediment of West Pond and the extremely low levels of phosphorus release or even phosphorus retention as well as the important factors affecting this condition. Accordingly, the important factors (both positive and negative) affecting phosphorus release can be listed as follows:

a) The structure of the sediment; the fact that it is made up of calcareous rock,

b) The facts that the largest phosphorus fraction in the sediment is stationary organic compounded phosphorus and that the level of organic matter in the sediment is not high enough to have an effect on phosphorus release,

c) Certain physical properties of the overlying water: water temperature, dissolved oxygen concentrations and $\mathrm{pH}$ were outside the values required to encourage phosphorus release.

\section{Conclusions}

The pond's sediment phosphorus release and phosphorus fractions were determined quantitatively in West Pond. Organically bound phosphorus fraction, made up the highest component of phosphorus in all cross-sections, play an important role in preventing phosphorus release from the sediment. The effectual inorganic phosphorus fractions component on preventing the sediment phosphorus release was mainly calcium bound phosphorus fraction due to the typical karstic limestone environment of the West Pond.

In consideration sediment is a sink not a source in terms of phosphorus in West Pond, there is no need to apply chemical treatment and dredging of sediment as a management technique to improve the water quality. Macrophyte roots are the main oxygen source for sediment, also play an important role in preventing or suppressing the dissolved inorganic phosphorus release from sediment to overlying water so it is necessary to conservate the 
rooted aquatic macrophytes in the littoral zone of the West Pond as a management technique. Moreover to maintain restoration over the long term, monitoring of the pond's sediment and water quality should be performed and also adsorption-desorption process of phosphorus can be studied in future research.

\section{Acknowledgements}

We greatly thank the financial support by the Research Foundation of Ankara University, Grant No: 09H4347002.

\section{References}

Akcora Topçu A (2001). Sakaryabaşı Batı Göleti’nin sediment gözenek suyunda fosforun mevsimsel değişimi. Yüksek Lisans Tezi, Ankara Üniversitesi Fen Bilimleri Enstitüsü Su Ürünleri Anabilim Dalı (Basılmamış), 49s, Ankara

Akcora Topçu A (2002). Sakaryabaşı (Çifteler-Eskişehir) Batı Göleti sedimentinin C:N oranı ile göletin besin seviyesi arasındaki ilişkinin araştırılması. Tarım Bilimleri Dergisi 8 (4): 289-292

APHA (1995). Standard Methods for the Examination of Water and Wastewater. $19^{\text {th }}$ edition. John D., Ducas Co., USA

Bostan V, Dominic J, Bostina M \& Pardos M (2000). Forms of particulate phosphorus in suspension and in bottom sediment in the Danube Delta. Lakes and Reservoirs, Research and Management 5: 105-110

Boyd C E, Taner M E, Madkour M \& Masuda K (1994). Chemical characteristics of bottom soils from freshwater and brackishwater aquaculture ponds. Journal of the World Aquaculture Society 25(4): 517-534

Eckert W, Nishri A \& Parparova R (1997). Factors regulating the flux of phosphate at the sediment-water interface of a subtropical calcareous lake: a simulation study with intact sediment cores. Water, Air and Soil Pollution 99: 401-409

Gerhardt S \& Schink B (2005). Redox changes of iron caused by erosion, resuspension and sedimentation in littoral sediment of a freshwater lake. Biochemistry 74: $341-356$

Günay G, Öcal F, Güven F \& Ergeneli N (2001). Sakaryabaşı karst kaynakları: hidrolojisi ve hidrojeolojisi. III. Ulusal Hidroloji Kongresi Bildiriler Kitab1, İzmir, Turkey

Hieltjes A H M \& Lijklema L (1980). Fractionation of inorganic phosphates in calcareous sediments. Journal of Environmental Quality 9(3): 405-407
Istvanovics V (1994). Fractional composition, adsorbtion and release of sediment phosphorus in the KissBalaton Reservoir. Water Resources 28 (3): 717-726

James W F, Best E P \& Barko J W (2004). Sediment resuspension and light attenuation in Peoria Lake: Can macrophytes improve water quality in this shallow system? Hydrobiologia 515: 193-201

Jiang C, Hu J, Huang X, Li C, Deng J, Zhang J \& Liu F (2011). Phosphorus speciation in sediments of Lake Hongfeng, China. Chinese Journal of Oceanology and Limnology 29(1): 53-62

Kırkağaç M \& Demir N (2006). Effects of grass carp (Ctenopharyngodon idella Val., 1844), on water quality, plankton, macrophytes and benthic macroinvertebrates in a spring pond. Turkish Journal of Fisheries and Aquatic Sciences 6: 07-15

Kisand A (2005). Distribution of sediment phosphorus fractions in hypertrophic strongly stratified Lake Verevi. Hydrobiologia 547: 33-39

Krogerus K \& Ekholm P (2003). Phosphorus in settling matter and bottom sediments in lakes loaded by agriculture. Hydrobiologia 429: 15-28

Marsden M W (1989). Lake restoration by reducing external phosphorus loading: the influence of sediment phosphorus release. Freshwater Biology 21: 139-162

Pulatsü S, Akcora Topçu A \& Köksal F (2003). Sediment and water phosphorus characteristics in a pond of spring origin, Sakaryabaşı Springs Basin, Turkey. Wetlands 23(1): 200-204

Pulatsü S \& Topçu A (2006). Sakaryabaşı Batı Göleti'nde (Türkiye) sedimentten fosfor salınmının tahmini. Ege Üniversitesi Su Ürünleri Fakültesi Dergisi 23 (1/1): 119-12

Ramm, K. and Scheps, V. (1997) Phosphorus balance of a polytrophic shallow lake with the consideration of phosphorus release. Hydrobiologia 342-343: 43-53

Qu W, Morrison R J \& West R J (2003). Inorganic nutrient and oxygen fluxes across the sediment-water interface in the inshore macrophyte areas of a shallow estuary (Lake Illawarra, Australia). Hydrobiologia 492: 119-127

Schneider S \& Melzer A (2004). Sediment and water nutrient characteristics in patches of submerged macrophytes in running waters. Hydrobiologia 527: 195-207

Shaw J F H \& Prepas E E (1990). Relationships between phosphorus in shallow sediments and in the trophogenic zone of Seven Alberta Lakes. Water Resources 24 (5): 551-556

Topçu A \& Pulatsü S (2011). Sakaryabaşı (ÇiftelerEskişehir) Balık Üretimi ve Araştırma İstasyonunun Su Kaynağı Batı Göleti: Sediment kaynaklı inorganik azot salınımının araştırılması. Ekoloji 20: 26-33 